\title{
The Interrelated Effects of Dietary Cholesterol and Fat upon Human Serum Lipid Levels *
}

\author{
William E. Connor, $\nmid$ Daniel B. Stone, $\ddagger$ and Robert E. Hodges \\ (From the Department of Internal Medicine, State University of Iowa College of Medicine, \\ Iowa City, Iowa)
}

Although many factors affect the serum lipid levels in man, cholesterol and fat in the diet have a most crucial influence. It has been known for decades that cholesterol given with fat in the diet would invariably elevate the serum cholesterol concentration in experimental animals and ultimately produce atherosclerosis $(2,3)$. Recently, myocardial infarction on the basis of severe coronary atherosclerosis has occurred in monkeys fed a diet rich in cholesterol and fat (4).

We have reported previously that cholesterol provided in a natural food greatly increased the serum cholesterol and phospholipid levels in man $(5,6)$. In these investigations, amounts of dietary cholesterol from 475 to $4,800 \mathrm{mg}$ per day caused the same degree of increase in serum cholesterol concentrations. Special care was taken in these investigations to keep dietary fat constant in both quantity and fatty acid composition, so that these factors did not influence the results. Egg yolk, with a cholesterol content of about $240 \mathrm{mg}$ per yolk, was a more potent hypercholesterolemic dietary component than pure crystalline cholesterol dissolved in oil. Others who have investigated the problems of dietary cholesterol in humans also found that the cholesterol of butterfat and egg yolk as well as pure cholesterol added to a vegetable oil produced increased serum cholesterol concentrations (7-11).

Changes in dietary fat may affect the serum lipids in several ways. The amount of fat may be

* Submitted for publication February 26, 1964 ; accepted April 23, 1964.

Presented in part at the 1961 Annual Meeting of the American Heart Association, Council on Arteriosclerosis (1).

Supported by U. S. Public Health Service research grants H-7239, H-4621, and AM 06090, and by the Iowa Heart Association.

$\dagger$ U. S. Public Health Service research career program award HE-K3-18406 from the National Heart Institute. $\ddagger$ Markle Scholar in Medical Science. important. When fat in the diet is below $40 \mathrm{~g}$ per day, the serum cholesterol concentration tends to fall although the earlier experiments illustrating this point did not always control other variable factors (12). Another factor is the fatty acid composition of the dietary fat. The substitution of polyunsaturated fat for saturated fat in the human diet generally has led to a lowering of serum cholesterol levels (13-18). Most investigators who have altered dietary fat composition by substituting polyunsaturated for saturated fat have used either cholesterol-free formula diets or diets with reduced cholesterol content. The most commonly eaten foods containing saturated fat, i.e., foods of animal origin, also have considerable cholesterol. The vegetable oils, used for their high content of polyunsaturated fatty acid, contain no cholesterol but considerable sitosterol, itself a serum cholesterol-lowering agent.

The possibly interrelated effects of these two factors, dietary fat and cholesterol, have not been studied in detail in human beings, particularly in men eating diets of mixed, natural foods. Our hypothesis was that dietary cholesterol is one factor which elevates the serum cholesterol level. On the other hand, polyunsaturated fat substituted for saturated fat has seemed to have a hypocholesterolemic effect. The purpose of the present study was to examine the effects of dietary cholesterol upon the serum lipids when the fatty acid composition of the diet was varied to provide different intakes of saturated and polyunsaturated fatty acids.

\section{Methods}

Subjects. Six men of average weight, ages 24 to 48 years, were kept for 16 weeks on a metabolic ward.1 Three men were healthy prison volunteers. The other

1 Subject 6, a diabetic subject, was obliged to withdraw from the study after the conclusion of period II because of illness in his family. 
TABLE I

Composition of the diets for the different dietary periods

\begin{tabular}{|c|c|c|c|c|c|c|c|c|c|c|}
\hline \multirow[b]{2}{*}{ Period } & \multirow[b]{2}{*}{ Cholesterol } & \multirow{2}{*}{$\begin{array}{c}\text { Iodine } \\
\text { number of } \\
\text { dietary fat }\end{array}$} & \multicolumn{3}{|c|}{$\begin{array}{l}\text { Fatty acid composition } \\
(\% \text { of total fat })\end{array}$} & \multicolumn{3}{|c|}{$\begin{array}{l}\text { Fatty acid composition } \\
\text { (\% of total calories) }\end{array}$} & \multirow{2}{*}{$\begin{array}{c}\text { Ratio of } \\
\text { polyunsatu- } \\
\text { rated to } \\
\text { saturated } \\
\text { fatty acids } \\
(\mathrm{P} / \mathrm{S})\end{array}$} & \multirow{2}{*}{$\begin{array}{c}\text { Phytosterol } \\
\text { content* }\end{array}$} \\
\hline & & & Saturated & Oleic & $\begin{array}{c}\text { Poly- } \\
\text { unsaturated }\end{array}$ & Saturated & Oleic & $\begin{array}{c}\text { Poly- } \\
\text { unsaturated }\end{array}$ & & \\
\hline & $m g / d a y$ & & & & & & & & & $m g / d a y$ \\
\hline I & 729 & 63 & 39.9 & 50.6 & 9.5 & 16.0 & 20.2 & 3.8 & 0.24 & 209 \\
\hline II & 0 & 64 & 37.4 & 53.1 & 9.5 & 14.9 & 21.2 & 3.8 & 0.25 & 237 \\
\hline III & 0 & 100 & 18.6 & 50.0 & 31.4 & 7.4 & 20.0 & 12.6 & 1.69 & 265 \\
\hline IV & 725 & 99 & 20.2 & 48.5 & 31.0 & 8.1 & 19.4 & 12.4 & 1.53 & 264 \\
\hline
\end{tabular}

* The phytosterol content of the diet was calculated from the data compiled by Lange (19).

three had unstable, juvenile-type diabetes, requiring insulin; they had had past episodes of acidosis and hypoglycemia. The previous diets of the prison volunteers had been the usual American diet; the diabetic patients had eaten previously the standard American Dietetic Association diabetic diet. On physical examination these diabetic patients had evidence of two complications of their disease, retinopathy and mild neuropathy. There were no signs of renal disease in any of these individuals. The health of all men remained constant for the duration of the study. Each man exercised at regular intervals each day. The three diabetic patients received insulin daily with the objective of good metabolic regulation.

Dietary plan. Each man received a diet of mixed, natural foods throughout four different dietary periods. There were three main meals with small in-between meal and bedtime feedings. The basal diet of 2,500 calories contained $100 \mathrm{~g}$ of protein, $280 \mathrm{~g}$ of carbohydrate (largely derived from cereals, fruits, vegetables, and skim milk), and $110 \mathrm{~g}$ of fat. The fat content was $40 \%$ of the total calories and always was derived from various mixtures of fats containing only long-chain fatty acids. All diets were designed to exceed minimal daily requirements for minerals and vitamins. The actual calorie intake of each man was calculated from his body build and estimated energy expenditure in order that body weight would remain constant throughout the study. Thus three subjects received 2,500 calories, and the three others 2,800,
3,000 , and 3,200 calories, respectively. Ingredients of the basic 2,500 calorie diet were increased proportionately to supply calories above the 2,500 calorie level. The percentage of total calories derived from protein, fat, and carbohydrate was kept similar in all diets. The phytosterol (sitosterols) content of diets in different periods ranged from 209 to $265 \mathrm{mg}$ per day (19).

The six men ate the four different diets in sequence, each for a period of 4 weeks. These diets were designed to differ only in fatty acid composition and cholesterol content (Tables I and II). During period I, the diet contained $729 \mathrm{mg}$ of cholesterol, derived from egg yolk and beef round steak. The fatty acid composition of this diet was $39.9 \%$ saturated, $50.6 \%$ monounsaturated, and only $9.5 \%$ polyunsaturated. The fat of this diet had an iodine number of about 63 , similar to that of the usual American diet eaten by the men before this study. In period II, cholesterol-containing foods were replaced in the diet by cholesterol-free foods. The fatty acid composition was kept virtually unchanged in each of the major components by the use of suitable combinations of vegetable fats. In period III, the diet remained cholesterol-free, but the amount of saturated fatty acid was reduced from $39.9 \%$ to $18.6 \%$, and the polyunsaturated fatty acid was increased from $9.5 \%$ to $31.4 \%$. The amount of monounsaturated fatty acid was not changed. The iodine number of the dietary fat thus increased from 64 to 100 . In period IV, $725 \mathrm{mg}$ of cholesterol in

TABLE II

Food sources of cholesterol and fat fed in the different dietary periods

\begin{tabular}{|c|c|c|c|c|c|c|c|c|}
\hline \multirow[b]{2}{*}{ Dietary period } & \multicolumn{2}{|c|}{ I } & \multicolumn{2}{|c|}{ II } & \multicolumn{2}{|c|}{ III } & \multicolumn{2}{|c|}{ IV } \\
\hline & Fat & Cholesterol & Fat & Cholesterol & Fat & Cholesterol & Fat & Cholesterol \\
\hline & $g$ & $m g$ & $g$ & & $g$ & & $g$ & $m g$ \\
\hline Egg yolk & 11.0 & 475 & & & & & 11.0 & 475 \\
\hline Beef round and suet & 16.5 & 254 & & & & & 5.6 & 250 \\
\hline Olive oil & 35.0 & & 35.0 & & 44.0 & & 50.5 & \\
\hline Cocoa butter & 45.0 & & 55.0 & & 5.0 & & 3.0 & \\
\hline Soybean oil & 5.0 & & & & 30.0 & & 20.0 & \\
\hline Peanut butter & & & 20.0 & & 20.0 & & & \\
\hline Safflower oil & & & & & 10.0 & & 20.0 & \\
\hline Totals & 112.5 & 729 & 110.0 & 0 & 109.0 & 0 & 110.1 & 725 \\
\hline
\end{tabular}


TABLE III

Mean serum lipid* values for different dietary periods

\begin{tabular}{|c|c|c|c|c|c|}
\hline & Subject $\dagger$ & $\begin{array}{c}\text { Period I } \\
\text { High cholesterol } \\
\text { lodine no. } 63\end{array}$ & $\begin{array}{c}\text { Period II } \\
\text { Cholesterol-free } \\
\text { Iodine no. } 64\end{array}$ & $\begin{array}{l}\text { Period III } \\
\text { Cholesterol-free } \\
\text { Iodine no. } 100\end{array}$ & $\begin{array}{l}\text { Period IV } \\
\text { High cholesterol } \\
\text { Iodine no. } 99\end{array}$ \\
\hline Cholesterol, $\mathrm{mg} / 100 \mathrm{ml}$ & $\begin{array}{l}1 \\
2 \\
3 \\
4 \\
5 \\
6\end{array}$ & $\begin{array}{l}209 \\
252 \\
260 \\
201 \\
187 \\
177\end{array}$ & $\begin{array}{l}171 \\
208 \\
188 \\
187 \\
147 \\
147\end{array}$ & $\begin{array}{l}167 \\
195 \\
200 \\
149 \\
158\end{array}$ & $\begin{array}{l}191 \\
213 \\
218 \\
178 \\
212\end{array}$ \\
\hline $\begin{array}{l}\text { Mean } \\
\text { Change } \\
\text { p }\end{array}$ & & $213 \pm 34$ & $\begin{array}{l}175 \pm 24 \\
-38 \\
<0.001\end{array}$ & $\begin{array}{c}174 \pm 23 \\
-1 \\
>0.5\end{array}$ & $\begin{array}{c}202 \pm 17 \\
+28 \\
<0.02\end{array}$ \\
\hline Phospholipid, mg/100 ml & $\begin{array}{l}1 \\
2 \\
3 \\
4 \\
5 \\
6\end{array}$ & $\begin{array}{l}173 \\
181 \\
183 \\
156 \\
158 \\
156\end{array}$ & $\begin{array}{l}131 \\
142 \\
138 \\
130 \\
122 \\
128\end{array}$ & $\begin{array}{l}136 \\
151 \\
137 \\
120 \\
136\end{array}$ & $\begin{array}{l}146 \\
151 \\
152 \\
160 \\
170\end{array}$ \\
\hline $\begin{array}{l}\text { Mean } \\
\text { Change } \\
\text { p }\end{array}$ & & $168 \pm 13$ & $\begin{array}{c}132 \pm 7 \\
-34 \\
<0.001\end{array}$ & $\begin{array}{c}136 \pm 11 \\
+4 \\
>0.4\end{array}$ & $\begin{array}{l}156 \pm 9 \\
+20 \\
<0.05\end{array}$ \\
\hline Triglyceride, $\mathrm{mg} / 100 \mathrm{ml}$ & $\begin{array}{l}1 \\
2 \\
3 \\
4 \\
5 \\
6\end{array}$ & $\begin{array}{r}90 \\
88 \\
93 \\
101 \\
125 \\
165\end{array}$ & $\begin{array}{r}75 \\
74 \\
86 \\
95 \\
97 \\
141\end{array}$ & $\begin{array}{r}76 \\
101 \\
96 \\
46 \\
87\end{array}$ & $\begin{array}{r}75 \\
102 \\
105 \\
74 \\
122\end{array}$ \\
\hline $\begin{array}{l}\text { Mean } \\
\text { Change } \\
\mathrm{p}\end{array}$ & & $110 \pm 30$ & $\begin{array}{l}95 \pm 25 \\
-16 \\
<0.01\end{array}$ & $\begin{array}{c}81 \pm 22 \\
-14 \\
>0.7\end{array}$ & $\begin{array}{c}96 \pm 21 \\
+14 \\
<0.2\end{array}$ \\
\hline
\end{tabular}

* Computed on the basis of determinations made during the last week of each dietary period.

$\dagger$ Subjects 1, 2, and 3 are normal men; Subjects 4, 5, and 6 are diabetic men.

the form of egg yolk and round steak was added to the diet, but the fatty acid composition and iodine number of the fat remained the same as in period III.

Laboratory studies. Venous blood was drawn twice weekly from each subject after a 14-hour fast. The concentrations of total cholesterol (20), phospholipid (21), and triglyceride (22) were determined in duplicate on each serum specimen. The free fatty acid concentration was measured in oxalated p'asma (23). Venous blood sugar was determined at regular intervals in the diabetic patients, both when fasting and 2 hours after meals (24). Twenty-four hour urinary sugar excretion of glucose was measured in order to assess further the state of diabetic control (25).

\section{Results}

The serum cholesterol concentrations of all six subjects declined from period I to period II when cholesterol was removed from the diet. This effect occurred despite a relatively saturated dietary fatty acid composition that had an iodine number of 64 (see Table III and Figure 1). The decrease in mean serum cholesterol concentration was $38 \mathrm{mg}$ per $100 \mathrm{ml}$ ( $\mathrm{p}<0.001)$, an $18 \%$ change. The serum phospholipid level declined 34 $\mathrm{mg}$ per $100 \mathrm{ml}(\mathrm{p}<0.001)$.

The serum lipids did not change during period III despite an increase in polyunsaturated fat and a decrease in saturated fat, giving a $P / S$ ratio of 1.7. The fat of this diet had an iodine number of 100 , and the diet remained cholesterol-free.

In period IV, the addition of $725 \mathrm{mg}$. of dietary cholesterol to the diet with an iodine number of 100 led to increased concentrations of the serum lipids. The serum cholesterol concentration increased $28 \mathrm{mg}$ per $100 \mathrm{ml}$ or $16 \%$ ( $\mathrm{p}<0.02)$. The serum phospholipid concentration increased concomitantly.

The normal subjects and diabetic patients had similar responses in the serum lipids when the cholesterol content of the diet was altered. The diabetic patients were free of ketonuria, but continued to have some glycosuria. Nearly all the specimens of 24-hour urine contained less than 32 

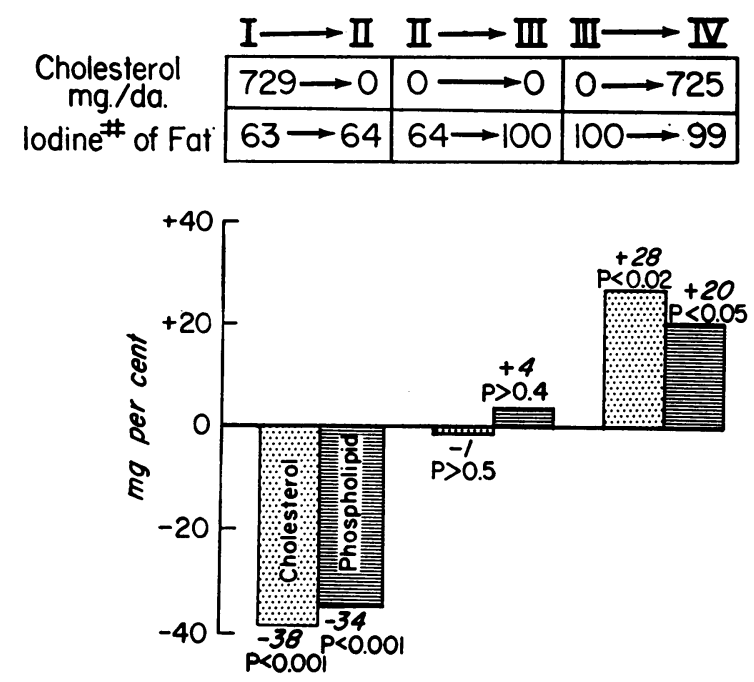

Fig. 1. Mean changes in Serum cholesterol and PHOSPHOLIPID CONCENTRATIONS OCCURRING FROM DIETARY PERIODS I TO II, II TO III, AND III to IV. The solid bars in the lower portion of the figure represent the serum lipid changes. In the upper portion of the figure is information about the diets in the different periods: the cholesterol content and the iodine number of the dietary fat.

$\mathrm{g}$ of glucose, the usual range being 2 to $20 \mathrm{~g}$. The majority of blood glucose values signified good control according to the criteria of CameriniDávalos, Root, and Marble (26). A minority indicated only fair control, but none indicated poor control. Neither the quantity of glycosuria nor the concentration of blood sugar had a trend that could be correlated with the different dietary periods. The fasting levels of plasma free fatty acids in the diabetic patients varied from 483 to $733 \mu \mathrm{Eq}$ per $\mathrm{L}$ without relationship to the different dietary periods.

The mean serum triglyceride level decreased slightly from 110 to $95 \mathrm{mg}$ per $100 \mathrm{ml}$ with the removal of cholesterol from the diet in period II. There were no significant changes in serum triglyceride concentrations during the other periods.

\section{Discussion}

The results of this study emphasize again that dietary cholesterol affects the serum cholesterol level in man. In our two previous experiments, dietary cholesterol elevated serum cholesterol concentrations in twelve healthy men when the iodine number of the dietary fat was about $85(5,6)$.
In this study the presence or absence of dietary cholesterol in an amount commonly eaten had a definite effect upon the serum cholesterol and phospholipid levels when the diet contained two different fatty acid compositions with iodine values of 64 and 100.

Of particular interest was the finding that the serum cholesterol concentration declined to $175 \mathrm{mg}$ per $100 \mathrm{ml}$ in period II when cholesterol was removed from the diet, despite a highly saturated dietary fat composition obtained through the use of cocoa butter. Malmros previously had observed in one subject that a cholesterol-free formula containing cocoa butter as the source of fat led to a lowering of the serum cholesterol level (27). Ahrens and associates have reported that two patients, No. 26 and 37 in their paper, had low serum cholesterol concentrations with the fat derived from cocoa butter but had considerable increase in serum cholesterol with the change to butter fat (16).

Another surprising result was that the serum lipids did not change as the fatty acid composition of the diet was made more unsaturated during the change from period II to period III. The fat fed in period III had an iodine value of 100 in contrast to an iodine value of 64 in period II. According to present day concepts, such a shift in fat composition should have produced a definite decrease in serum lipid levels (12). Instead the mean serum cholesterol and phospholipid concentrations remained unchanged.

In explanation of these effects, we stress the point that our subjects were receiving a cholesterol-free diet in both periods II and III. Their serum cholesterol levels had already been reduced to a low figure by the previous removal of cholesterol from the diet. Most other studies of this problem have differed in experimental design from our study in several ways. Some of the diets used have contained cholesterol, since the importance of this constituent may not have been considered at the time $(28,29)$. In other experiments, coconut oil, a fat having a very low iodine value, has been compared with corn oil, highly polyunsaturated. As Ahrens has pointed out, however, coconut oil is composed largely of short-chain fatty acids whose metabolism in the body differs greatly from the metabolism of the long-chain fatty acids 
of corn oil $(12,16)$. Studies of the contrasting effects of coconut oil and corn oil will not provide an answer to the "saturated versus polyunsaturated fat" question, since these fats have fatty acids of greatly different chain lengths. Butterfat contains both cholesterol and short-chain fatty acids as well as long-chain saturated fatty acids. Thus studies of "butterfat versus corn oil" involve at least two additional variables in addition to differences in the amounts of saturated and polyunsaturated fat. Finally, the patients in other studies of this problem have sometimes had a profound degree of hypercholesterolemia, up to $500 \mathrm{mg}$ per $100 \mathrm{ml}$ (16). Patients with hypercholesterolemia and xanthomatous disease may differ greatly in their metabolic responses from the subjects of our present study whose serum cholesterol levels were in a much lower range.

An additional explanation for the lack of change in serum lipids from period II to period III when dietary fat was made more unsaturated might be that the degree of unsaturation (iodine value of 100) was simply not enough to produce the expected change, although the summary of Ahrens suggests that fats like peanut oil (iodine value, 80 to 90 ) had no less serum cholesterol lowering effect than corn oil (iodine value of 126) (16). In most of these experiments, however, corn oil is compared with a more saturated fat such as palm oil. To our knowledge, in no previous experiment involving a cholesterol-free diet was a fat having an iodine value of 95 to 100 compared with a more saturated fat with an iodine value of 60 to 70 .

Two recent experiments provide a comparison between fats having iodine values of 76 and 95 (30) and 38, 84, and 105 (10). In both experiments cholesterol-free formulas were fed to normocholesterolemic subjects. The serum cholesterol levels remained unchanged despite drastic alterations in the fatty acid composition of the diets.

Considerable emphasis has been placed upon the development of formulas for the quantitative prediction of shifts in the serum cholesterol concentration when the fatty acid composition of the diet has been altered. Keys, Anderson, and Grande have stated that the change in serum cholesterol level in $\mathrm{mg}$ per $100 \mathrm{ml}$ equals $2.74 \Delta \mathrm{S}-1.31 \Delta \mathrm{P}$, where $\mathrm{S}=$ the percentage of total calories derived from saturated fat, and $\mathrm{P}=$ the percentage of total calories derived from polyunsaturated fat (28).

The application of this formula to the dietary periods of this study led to the following calculated results. From period I to II, the use of the formula would predict no change in the serum cholesterol level. As noted, the mean serum cholesterol level actually declined $38 \mathrm{mg}$ per $100 \mathrm{ml}$. From period II to III, the application of the formula would predict a decline of $32 \mathrm{mg}$ per $100 \mathrm{ml}$ in serum cholesterol level. The actual change was only $2 \mathrm{mg}$ per $100 \mathrm{ml}$. Finally, from period III to IV, with the formula, no change in serum cholesterol level would be expected, whereas there was actually an increase of $28 \mathrm{mg}$ per $100 \mathrm{ml}$. Apparently the cholesterol content of the diet was an important factor not considered by this prediction formula. These observations do not deny the general validity of this formula but do indicate the importance of another dietary lipid.

\section{Summary}

1) In diets of mixed, natural foods controlled in fat content and composition, the presence or absence of cholesterol influenced greatly the serum cholesterol and phospholipid levels in six men. The removal of cholesterol from the diet produced a decrease of $38 \mathrm{mg}$ per $100 \mathrm{ml}$ in the mean serum cholesterol concentration despite a diet containing a large quantity of saturated fat. The addition of $725 \mathrm{mg}$ of dietary cholesterol caused an increase in the mean serum cholesterol concentration even when the diet contained a high content of polyunsaturated fat.

2) The concentration of serum lipids remained unchanged during two periods of cholesterol-free diets when the fatty acid composition of the dietary fat was made more polyunsaturated and less saturated (from an iodine number of 63 to 100 ).

3) The results of this study emphasize again the important influence of dietary cholesterol upon the serum lipids. The effects of changes in dietary fat composition in the ranges tested were minor in comparison to those caused by changes in the dietary intake of cholesterol.

4) The serum lipids of both healthy men and diabetic patients responded similarly to these dietary changes. 


\section{Acknowledgment}

We thank Dr. Edward H. Ahrens, Jr., of the Rockefeller Institute, for his criticisms of the experimental design.

\section{References}

1. Connor, W. E., D. B. Stone, and R. E. Hodges. Differential effects of dietary cholesterol and fat upon human serum lipid levels and fecal sterols (abstract). Circulation 1961, 24, 1088.

2. Anitschkow, N. Experimental arteriosclerosis in animals in Arteriosclerosis, E. V. Cowdry, Ed. New York, Macmillan, 1933, p. 271.

3. Katz, L. N., J. Stamler, and R. Pick. Nutrition and Atherosclerosis. Philadelphia, Lea \& Febiger, 1958.

4. Taylor, C. B., G. E. Cox, P. Manalo-Estrella, J. Southworth, D. E. Patton, and C. Cathcart. Atherosclerosis in Rhesus monkeys. II. Arterial lesions associated with hypercholesteremia induced by dietary fat and cholesterol. Arch. Path. 1962, 74, 16.

5. Connor, W. E., R. E. Hodges, and R. E. Bleiler. Effect of dietary cholesterol upon serum lipids in man. J. Lab. clin. Med. 1961, 57, 331.

6. Connor, W. E., R. E. Hodges, and R. E. Bleiler. The serum lipids in men receiving high cholesterol and cholesterol-free diets. J. clin. Invest. 1961, 40, 894.

7. Beveridge, J. M. R., W. F. Connell, G. A. Mayer, and H. L. Haust. The response of man to dietary cholesterol. J. Nutr. 1960, 71, 61.

8. Steiner, A., E. J. Howard, and S. Akgun. Importance of dietary cholesterol in man. J. Amer. med. Ass. 1962, 181, 186.

9. Wells, V. M., and B. Bronte-Stewart. Egg yolk and serum-cholesterol levels: importance of dietary cholesterol intake. Brit. med. J. 1963, 1, 577.

10. Erickson, A., R. H. Coots, F. H. Mattson, and A. M. Kligman. Effect of $\mathrm{P} / \mathrm{S}$ ratio, partial hydrogenation of dietary fats, and dietary cholesterol upon plasma cholesterol in man (abstract). Circulation 1963, 28, 656.

11. Anderson, J. T., F. Grande, C. Chlouverakis, M. Proja, and A. Keys. Effect of dietary cholesterol on serum cholesterol level in man. Fed. Proc. 1962, 21, 100.

12. Ahrens, E. H., Jr. Nutritional factors and serum lipid levels. Amer. J. Med. 1957, 23, 928.

13. Kinsell, L. W., J. Partridge, L. Boling, S. Margen, and G. Michaels. Dietary modifications of serum cholesterol and phospholipid levels. J. clin. Endocr. 1952, 12, 909.

14. Ahrens, E. H., Jr., D. H. Blankenhorn, and T. T. Tsaltas. Effect on human serum lipids of sub- stituting plant for animal fat in diet. Proc. Soc. exp. Biol. (N. Y.) 1954, 86, 872.

15. Keys, A., J. T. Anderson, and F. Grande. Serumcholesterol response to dietary fat. Lancet 1957, 1, 787.

16. Ahrens, E. H., Jr., J. Hirsch, W. Insull, Jr., T. T. Tsaltas, R. Blomstrand, and M. L. Peterson. The influence of dietary fats on serum-lipid levels in man. Lancet 1957, 1, 943.

17. Bronte-Stewart, B., A. Antonis, L. Eales, and J. F. Brock. Effects of feeding different fats on serumcholesterol level. Lancet 1956, 1, 521.

18. Beveridge, J. M. R., W. F. Connell, and G. A. Mayer. Dietary factors affecting the level of plasma cholesterol in humans: the role of fat. Canad. J. Biochem. 1956, 34, 441.

19. Lange, W. Cholesterol, phytosterol, and tocopheral content of food products and animal tissues. J. Amer. Oil Chemists' Soc. 1950, 27, 414.

20. Abell, L. L., B. B. Levy, B. B. Brodie, and F. E. Kendall. A simplified method for the estimation of total cholesterol in serum and demonstration of its specificity. J. biol. Chem. 1952, 195, 357.

21. Dryer, R. L., A. R. Tammes, and J. I. Routh. The determination of phosphorus and phosphatase with $N$-phenyl-p-phenylenediamine. J. biol. Chem. 1957, 225, 177.

22. Van Handel, E., and D. B. Zilversmit. Micromethod for the direct determination of serum triglycerides. J. Lab. clin. Med. 1957, 50, 152.

23. Dole, V. P., and H. Meinertz. Microdetermination of long-chain fatty acids in plasma and tissues. J. biol. Chem. 1960, 235, 2595.

24. Nelson, N. A photometric adaptation of the Somogyi method for the determination of glucose. J. biol. Chem. 1944, 153, 375.

25. Benedict, S. R. The detection and estimation of glucose in urine. J. Amer. med. Ass. 1911, 57, 1193.

26. Camerini-Dávalos, R., H. F. Root, and A. Marble. Clinical experience with carbutamide (BZ 55). A progress report. Diabetes 1957, 6, 74.

27. Malmros, H. The effect of dietary fats on serum cholesterol in Essential Fatty Acids, H. M. Sinclair, Ed. London, Sinclair, Butterworth Scientific Publications, 1958, p. 150.

28. Keys, A., J. T. Anderson, and F. Grande. Prediction of serum-cholesterol responses of man to changes in fats in the diet. Lancet 1957, 2, 959.

29. Anderson, J. T., F. Grande, and A. Keys. Hydrogenated fats in the diet and lipids in the serum of man. J. Nutr. 1961, 75, 388.

30. McOsker, D. E., F. H. Mattson, H. B. Sweringen, and A. M. Kligman. The influence of partially hydrogenated dietary fats on serum cholesterol levels. J. Amer. med. Ass. 1962, 180, 380. 